\title{
KONSEP DESAIN INFOGRAFIS GEDUNG VILLA NOVA JAKARTA SEBAGAI MEDIA PENDIDIKAN SEJARAH
}

\author{
Azhari Amri' ${ }^{1)}$ dan Huddy Husin ${ }^{2)}$ \\ ${ }^{1)}$ Program Studi Desain Komunikasi Visual \\ ${ }^{2}$ Program Studi Pendidikan Sejarah \\ Universitas Indraprasta PGRI \\ ${ }^{1)}$ azhariamri86@gmail.com dan ${ }^{2)}$ hoedy_02@yahoo.com
}

\begin{abstract}
Abstrak
Keberadaan bangunan Villa Nova saat ini sudah memprihatinkan dan jauh dari sebuah tempat sejarah, bentuk bangunan yang sudah rusak karena kebakaran dan area lahan yang sudah disorientasi fungsi dari yang seharusnya dikatakan sebagai cagar budaya adalah hal persoalan mendasar tetapi sangat vital apabila tidak diselesaikan. Melalui dua pendekatan desain dan sejarah, penelitian ini akan kembali merekonstruksi sejarah di balik keberadaan bangunan Villa Nova untuk menganalisis cerita, bentuk, fungsi dan kepentingan di zamannya. Keberadaan bangunan yang tidak mampu lagi dihadirkan dan diperbaiki kembali secara fisik, menjadi hal yang patut diangkat dan dihadirkan kembali dalam bentuk media informasi yang menarik dalam bentuk desain infografik rekonstruksi sejarah gedung Villa Nova Jakarta.
\end{abstract}

Kata Kunci : Desain, Infografis, Pendidikan, Sejarah

\begin{abstract}
The existence of Villa Nova building nowadays is worrisome and could be not impressed as a historical building. The damaged building that caused by fire and also the disoriented function of the land area which should be known as cultural heritage is a fundamental problem yet important to be solved. Through design and history approach, this research will reconstructs the history behind the existence of Villa Nova building by analized the story, form, function and prominance of its era. The existence building that have not be able to be presented and physically repaired are being matters that should be appointed into attractive infographic media of reconstruction the history of Villa Nova building Jakarta.
\end{abstract}

Keyword: Design, infographic, education, history 


\section{PENDAHULUAN}

Desain komunikasi visual sebagai pengetahuan baru yang kompleks, kini telah menghadapi tantangannya di masyarakat. Dengan kompentensi kemampuan seni, teknologi dan ilmu-ilmu lain yang dapat saling berintegrasi, membuat desain komunikasi visual mempunyai ruang positif yang berbeda dari ilmu-ilmu lain yang hadir di Indonesia. Walaupun positioning di masyarakat menempatkan desain komunikasi visual sebagai suatu ilmu terapan, justru menjadi tantangan sendiri bagi peneliti untuk mampu membuktikan integrasi ilmu desain komunikasi visual dengan ilmu lain agar dapat bermanfaat bagi masyarakat, lembaga dan Negara Republik Indonesia.

Melalui model penelitian terapan yang terintegrasi dengan ilmu lain inilah, menjadi menarik apabila desain komunikasi visual membuktikan sumbangsihnya agar bermanfaat bagi masyarakat. Melalui penelitian ini, peneliti mencoba mengintegrasikan antara desain komunikasi visual dengan ilmu sejarah sebagai langkah strategis dalam menghadirkan wujud informasi sejarah dalam bentuk desain infografik. Model penciptaan berupa karya desain infografik kini sudah mulai dipraktekkan menjadi media informasi yang atraktif dan menarik untuk menyebarluaskan wawasan baru maupun yang lampau untuk dihadirkan kembali secara aktual (mengikuti perkembangan media yang ada sekarang) agar generasi muda saat ini dapat mempelajarinya. Penelitian ini akan memfokuskan salah satu cerita sejarah yang ada di Kota Jakarta. Bangunan sebagai objek atau bukti sejarah yang kini sudah luluh lantak dan telah menjadi cagar budaya, hendak peneliti rekonstruksi kembali informasinya untuk menjadi sebuah karya desain infografik yang tetap berlandaskan kaidah objektif dan ilmiah.

Jakarta sebagai sebuah Ibu Kota Negara Republik Indonesia mestinya menjadi garda terdepan dalam usaha memperjelas informasi dan mengapresiasi kehadiran cagar budaya yang ada di setiap titik daerahnya. Apresiasi tersebut kini harus dimunculkan dalam metode terapan baru sebagai sebuah wacana pembelajaran bagi generasi muda Jakarta atas sejarah yang perlu disampaikan secara bertahap dan berkelanjutan. Salah satu konteks cagar budaya sejarah Jakarta yang menarik perhatian peneliti ialah adanya peninggalan bangunan Villa Nova yang terletak di daerah Condet Jakarta Timur.

Bangunan Villa Nova saat ini terletak di komplek asrama polisi, di Kelurahan Gedong, Kecamatan Pasar Rebo, Jakarta Timur. Keadaan bangunan peninggalan Belanda tersebut hanya tersisa kerangka utamanya, hal itu disebabkan terjadinya ledakan pada tahun 1985. Kehadiran bangunan ini adalah bukti dari sejarah Kota Jakarta yang perlu diangkat kembali sebagai warisan cerita sejarah daerah di Jakarta Timur. Sejarah bangunan Villa Nova tidak lepas dari sejarah pemberontakkan rakyat yang pada waktu itu dipimpin oleh Haji Entong Gendut, hal ini juga ditegaskan oleh Alwi Shahab dalam sebuah bukunya yaitu Betawi; Queen Of The East,

Sebuah monumen sejarah, setidaknya bisa menjadi saksi bisu betapa rakyat dengan gigih melawan kesewenanganwenangan. Dia adalah sebuah gedung yang telah luluh lantak dimakan api sekitar tahun 1970-an. Itulah gedung yang dibangun pada 1740 , letaknya dihadapan Rindam Jaya, bagian paling selatan dari kawasan Condet. Gedung yang tinggal puing-puing dri tempo dulu merupakan satu-satunya gedung termegah disana. Hingga kemudian mengubah sebutan kawasan disana menjadi kampong Gedong sampai saat 
ini. Gedung yang pernah dipakai sebagai asrama Brimob ini, dulu merupakan Landhuis atau villa, tempat timggal tuan tanag Belanda atau yang dahulunya bernama Tanjung Oost kini menjadi Jalan Tanjung Timur, (Shahab, $2002: 64$ ).

Kisah gedung ini juga tercatat di http://history.peschfamily.com/, situs keluarga keturunan pembangun dan pemilik pertama gedung ini dari klan Van Riemsdijk. Keturunan Van Riemsdijk, Tjalling Ament dan Dina Cornelia yang meninggal tahun 1870 dan 1877, sebelum pemberontakan Entong Gendut 1916, dimakamkan di TPU Gedong (www.news.detik.com, diunduh 19 April 2015). Selanjutnya, deskripsi bangunan tersebut merupakan bangunan tingkat dua, yang letaknya berada di dataran tinggi hingga membuat bangunan tersebut seperti gedung yang megah dari sudut pandang kejauhan. Dahulu kondisi geografis di sekitar gedung adalah kawasan yang masih rimbun ditumbuhi berbagai pepohonan, membuat keberadaan bangunan tinggi satu-satunya tersebut menonjol di wilayah tersebut.

Jadi, sejak tahun 1800an, warga Batavia lebih mengenal Tanjung Timur dengan nama kampung gedong. Sebab ada satu bangunan besar (gedung, red) milik tuan tanah yang berdiri di tengah-tengah tanah pertanian dan perkebunan milik tuan tanah Belanda yang mendominasi wilayah ini, (Dokumentasi wawancara Maryadie, Zaky Al-Yamani dengan Wak Djejeh (70) Sesepuh Kampung Gedung, www.metro.news.viva.co.id, diunduh 19 April 2015).

Bangunan bergaya Eropa klasik yang memiliki luas 100 meter ini diapit oleh dua menara besar tiga lantai. Lantai dasar menara digunakan sebagai penjara bawah tanah untuk dikhususkan kepada para pemberontak. Bangunan utama berlantai dua memiliki empat ruang kamar besar di tiap lantainya. Hingga tahun 1980an, halaman sekitar gedung masih dipenuhi pohon besar seperti pohon Asem dan Gandaria. Di halaman depan gedung, terdapat meja batu yang biasa dipergunakan sebagai tempat menanam kepala kerbau untuk keperluan sesajen pada masa itu. Sejarah mencatat, kawasan kampung Gedong awalnya bernama tanah partikelir Tanjoeng Oost (Tanjung Timur).

Kondisi bangunan Villa Nova saat ini sudah memprihatinkan, bentuk bangunan yang sudah rusak karena kebakaran dan area lahan yang sudah disorientasi fungsi dari yang seharusnya dikatakan sebagai cagar budaya adalah hal persoalan mendasar tetapi sangat vital apabila tidak diselesaikan. Keberadaan bangunan yang tidak mampu lagi dihadirkan dan diperbaiki kembali secara fisik, menjadi hal yang patut diangkat dan dihadirkan kembali dalam bentuk media informasi yang menarik. Maka dari itulah, peneliti sangat menaruh perhatian besar untuk menempatkan bangunan ini sebagai objek penelitian yang menarik untuk disusun menjadi suatu cerita sejarah yang dapat dipelajari oleh generasi muda Jakarta khususnya pemerintah daerah masyarakat di daerah Condet, Jakarta Timur.

Beberapa hal yang menjadi dasar peneliti menempatkan bangunan Villa Nova sebagai objek cerita sejarah yang akan dijadikan desain infografik adalah pertama, bangunan ini adalah salah satu simbol yang dapat menarik garis sejarah dinamika masyarakat Condet, Jakarta Timur pada masa penjajahan hingga pasca kemerdekaan. Kedua, karena bukti bangunan ini sudah luluh lantak dan tidak tergambarkan dengan jelas secara fisik maka menjadi penting untuk menghadirkan kembali simulasi bangunan sejarah tersebut dalam bentuk yang dinamis agar informasi sejarah dapat tersampaikan dengan jelas. Ketiga, dengan mengangkat dan merekonstruksi cerita di balik bangunan sejarah Villa 
Nova, telah menempatkan desain komunikasi visual sebagai ilmu yang juga mampu berintegrasi dengan ilmu sejarah dengan menempatkan peranannya secara kritis dalam memperjelas dan menyebarluaskan cerita sejarah agar dapat dipelajari masyarakat.

Berdasarkan hal itulah peneliti menempatkan gagasan atas perlunya menciptakan Desain Infografik Rekonstruksi Sejarah Villa Nova Jakarta sebagai sebuah penelitian yang strategis dalam menyelesaikan persoalan sejarah di Kota Jakarta, sekaligus juga menghadirkan proses pembelajaran sejarah dalam bentuk historiografi yang terejawantahkan oleh desain komunikasi visual dalam sebuah karya infografik.

\section{Rumusan Masalah}

Agar dapat mencapai fokus penelitian secara obyektif dan aktual, maka peneliti menjabarkan rumusan penelitian sebagai berikut:

1. Bagaimana latar belakang cerita sejarah di balik bangunan Villa Nova Jakarta pada masa penjajahan hingga pasca kemerdekaan?

2. Bagaimana Konsep Desain Infografis Gedung Villa Nova Sebagai Media Pendidikan Sejarah?

\section{Tujuan Penelitian}

Penelitian ini memiliki tujuan mendasar dalam menyelesaikan persoalan, di antaranya yaitu,

1. Mengetahui latar belakang cerita sejarah di balik bangunan Villa Nova Jakarta pada masa penjajahan hingga pasca kemerdekaan.

2. Menyusun Konsep Desain Infografis Gedung Villa Nova sebagai Media Pendidikan Sejarah

\section{METODE PENELITIAN}

Jenis penelitian yang digunakan dalam penelitian ini ialah jenis kualitatif.
Penjelasan lebih lanjut diterangkan oleh Levi Strauss dalam Ratna (2010: 97),

Kualitatif adalah peneliti dalam dirinya sendiri atau dalam pengertian lain yaitu bricolor, manusia serba bisa atau seorang pribadi yang mandiri dan profesional. Secara metaforis disebutkan sebagai manusia yang dapat menghasilkan segala sesuatu dengan apa yang ada di tangan. Hasilnya adalah bricolage, suatu analisis yang kompleks, reflektif, padat, mirip kliping, yang secara keseluruhan mewakili interpretasi penelitian penuh makna.

Dari pengertian di atas Denzin dan Lincoln menjelaskan lebih lanjut bahwa,

Proses kualitatif merupakan proses interaktif yang dibentuk sejarah personal, biografi, gender, kelas sosial, ras, etnis dan sebagainya, dengan sudut pandang yang berbeda sebagai perbedaan gaya, epistemologi, dan representasi (Ratna, 2010: 101).

Pendekatan pertama menggunakan pendekatan sejarah dan pendekatan yang kedua adalah pendekatan proses kreasi dimana hasil akhirnya adalah perancangan visual. Pendekatan Sejarah meongungkapan fakta mentalitas yang berwujud sistem nilai, pola sosial, identifikasi adaptasi, tingkat resistensi sosial masa lampau sebagai dinamika sosial yang mencerminkan citra sosial dimasa lalu, kemudian dihubungkan dengan masa kini. Hal ini untuk melihat proses gejala secara kritis yang terdapat dalam objek penelitian. Salah satu metode pendekatannya adalah metode historiografi (Gottschalk, 1985:57) dalam Amri (2013) yang langkahlangkahnya sebagai berikut,

Tahap pertama ialah Heuristic yaitu pencarian sumber-sumber sejarah menyeluruh dan sebanyakbanyaknya), tahap kedua adalah tahap 
kritik (tahap adalah adalah tahap seleksi atas sumber-sumber tersebut), tahap ketiga adalah tahap interpretasi yaitu penafsiran terhadap data yang sudah diseleksi yang di dalamnya terdapat analisis. Kemudian tahap keempat adalah historiografi adalah mengaktualisasikan hasil penafsiran ke dalam bentuk tulisan, sehingga sejarah menjadi tulisan yang hidup dan tidak kering atas penjabaran menghidupkan suatu kejadian tanpa meninggalkan aspek kritis, (Amri, 2013: 96).

Sedangkan Pendekatan selanjutnya menggunakan proses kreatif penciptaan karya. Hospers (1982: 192) dalam Amri menjelaskan,

Penelitian ini bersifat penciptaan, hal itu dikarenakan ketika ekspresi sebagai bentuk pengungkapan perasaan atau pernyataan terdalam ke dalam wujud yang bisa diamati maka proses pewujudannya membutuhkan metode dan teknik (Hospers dalam Amri, 2013:98).

Selanjutnya, Hawkins (dalam Gustami 2004:13-15) menjelaskan bahwa metode penciptaan terdiri atas beberapa tahapan penciptaan: eksplorasi ide, improvisasi maupun eksperimentasi, dan pewujudan. Dalam konteks ini, intuitif sebenarnya telah berada dalam wilayah improvisasi atau eksperimentasi dan pewujudan.

\section{Analisis Data}

Analisis data yang digunakan oleh peneliti merupakan serangkaian praktik penelitian dengan pendekatan sejarah dan proses kreasi. Tahapan ini sekaligus bagian dari analisis penelitian yang akan dilakukan dengan hasil akhir berupa perancangan infografik. Tahap pertama peneliti akan melakukan proses Heuristic yaitu pencarian sumber-sumber sejarah menyeluruh dan sebanyak-banyaknya), tahap kedua adalah tahap kritik (tahap adalah adalah tahap seleksi atas sumber- sumber tersebut), tahap ketiga adalah tahap interpretasi yaitu penafsiran terhadap data yang sudah diseleksi yang di dalamny terdapat analisis. Kemudian tahap keempat adalah historiografi adalah mengaktualisasikan hasil penafsiran ke dalam bentuk tulisan, sehingga sejarah menjadi tulisan yang hidup dan tidak kering atas penjabaran menghidupkan suatu kejadian tanpa meninggalkan aspek kritis. Selanjutnya peneliti akan melakukan proses eksplorasi ide, improvisasi maupun eksperimentasi, dan pewujudan sebagai bagian dari proses penciptaan.

\section{HASIL DAN PEMBAHASAN}

\section{Keadaan Umum Geografis, Kehidupan Sosial-Ekonomi Jakarta, dan Tinjauan Singkat Sejarah Bangunan Villa Nova.}

Gambaran Umum Keadaan Geografis dan Kehidupan Sosial-Ekonomi Jakarta

Kemunculan Jakarta sebagai sebuah kota modern saat ini tidaklah terlepas dari usaha adaptasi dan rekayasa sosial dari tangan-tangan manusia. Upaya adaptasi dan respon manusia terhadap lingkungan ekologi wilayah Jakarta, dapat terlihat dari perubahan fisik kota Jakarta dan perubahan dalam dimensi sosial masyarakatnya, yang selalu bergerak secara dinamis dan progresif sesuai dengan arah perkembangan dan pemenuhan kebutuhan dari masyarakat di dalamnya. Jakarta yang kita kenal saat ini sebagai sebuah kota pusat pemerintahan, dan centrum dari kehidupan sosial, ekonomi dan cultural bukanlah sebuah kota yang secara tiba-tiba menjelma menjadi sebuah kota besar dan modern seperti sekarang ini, akan tetapi sebagai sebuah akumulasi prosesual yang kompleks, dari jalinan relasi sosialekonomi dan politik yang tercermin dalam keunikan aspek kulturalnya. 
Sebagai sebuah daerah yang berada di pesisir dan berdekatan dengan daerah-daerah pedalaman yang memiliki wilayah yang subur, Jakarta kemudian muncul sebagai semacam daerah pengumpul hasil-hasil bumi yang berasal dari daerah pedalaman. Secara umum letak geografis Jakarta berada antara $106^{\circ}$ 22' 42" BT sampai dengan 106 58'18" BT, dan antara $5^{\circ} 19^{\prime} 12^{\prime \prime}$ LS sampai dengan $6^{\circ}$ 23'54" LS. Daerah Jakarta diapit oleh daratan di sebelah barat, timur dan selatan, dan laut di sebelah utara. Di sebelah barat daerah Jakarta bersebelahan dengan daerah Banten, di sebelah selatan Jakarta berbatasan langsung dengan wilayah Depok, sementara itu di sebelah timur Jakarta berbatasan dengan daerah Bekasi dan di utara berbatasan dengan laut Jawa.

Keadaan morfologis Jakarta secara umum tersusun atas daratan aluviall yang dihasilkan oleh endapan tanah dari sungai Ci Liwung, Kali Bekasi dan Sungai Cisadane. Endapan tanah tersebut kemudian membentuk aluviall fan (kipas), semua endapan tanah tersebut berasal dari Gunung Salak dan Gunung Gede, yang kemudian bermuara di daerah dataran rendah Jakarta selama berabadabad. Tanah dengan jenis aluviall tersebut memiliki unsur hara yang bagus dan, merupakan tanah yang cukup baik untuk membangun mata pencaharian melalui pertanian dan perkebunan. Upaya untuk membangun mata pencaharian pertanian dan perkebunan di wilayah Jakarta juga di dukung oleh keadaan iklim Jakarta yang bersifat hujan hutan tropis, dengan curah hujan rata-rata pertahun mencapai 1.857 mm dibagian utara Jakarta dan $3.167 \mathrm{~mm}$ di bagian selatan Jakarta. Dengan keadaan demikian maka tidaklah mengherankan jika Jakarta merupakan kota yang diberikan kelimpahan sumber daya air yang cukup besar.

Keberadaan di pesisir Laut Jawa yang notabene sebagai jalur pelayaran nusantara membuat Jakarta (Batavia) saat itu menjadi salah satu wilayah transit perdagangan, kemudian tiga sungai besar yang mengalir di wilayah Jakarta menjadi denyut nadi jalur tansportasi air yang menghubungkan Jakarta dengan daerahdaearah pedalaman di Jawa Barat yang banyak menghasilkan produk-produk hasil bumi. Dengan bermodalkan pelabuhan dan hubungan ditopang oleh sarana transportasi air ke wilayah pedalaman Jawa Barat, maka sekiranya tepat jika kemudian Jakarta muncul sebagai sebuah wilayah yang cukup mumpuni dalam aspek sosial-ekonomi dan politik. Keadaan lingkungan geografis tersebut yang kemudian membangun kesadaran dari masyarakatnya mengenai posisi kota Jakarta terhadap keberadaan daerahdaerah lainnya yang dapat menjadi penyangga bagi keberlangsungan kota Jakarta dan sebagai fasilitator bagi daerah pedalaman untuk berinteraksi dengan dunia luar.

Kehidupan ekonomi dan pusat kekuatan politik pemerintahan pada masa kolonial Belanda tidak hanya berdampak pada semakin menguatnya posisi Jakarta (pada saat itu bernama Batavia) dalam denyut nadi kehidupan di Pulau Jawa, akan tetapi juga memberikan dampak berupa perluasan areal wilayah kota Jakarta itu sendiri. Berkaitan dengan perluasan kota, setelah Batavia menjadi Gemeente ditahun 1905, pada tahun 1926 kota Batavia tercatat memiliki luas sekitar $182 \mathrm{~km}^{2}$, dan belum memasukkan wilayah Meester Cornelis ke dalam wilayah Batavia. Baru kemudian pada tahun 1935 wilayah Meester Cornelis dimasukkan ke dalam wilayah Batavia. Secara berturut dan bertahap terjadi perluasan kota Jakarta setelah Indonesia merdeka, tercatat pada tahun 1950 luas Kota Praja Jakarta Raya mencapai 530 $\mathrm{km}^{2}$, tahun 1967 adalah 590,11 km², dan pada tahun 1978 luasnya menjadi $654,90^{2}$ 
km (Gunawan dalam Abdullah dan Abdurrachman, 2011: 110; Blackburn, 2011: 124; Castles, 2007: 19).

Meester Cornelis merupakan wilayah yang berada di sebelah timur kota Batavia, wilayah ini memayungi daerah-daerah yang cukup dikenal di Batavia seperti Cililitan, Pasar Rebo, Condet, dan Tanjung Timur (sekarang lebih dikenal dengan nama Kampung Gedong). Wilayah Meester Cornelis ini dikenal pula pada masa kolonial Belanda sebagai wilayah tanah partikelir (tanah yang disewakan) yang peruntukkannya dinilai dapat menghasilkan nilai ekonomis bagi pemerintah kolonial. Dalam sejarah Indonesia, khususnya yang berkaitan dengan tema-tema sejarah sosial dan ekonomi, keberadaan tanah partikelir selain sebagai sumber ekonomi bagi pemerintah dan pihak swasta sebagai penyewa, juga memberikan implikasi yang cukup luas dalam kehidupan sosial masyarakat yang berada di sekitar tanah partikelir tersebut (ANRI, 1973:LIX).

Jenis tanah yang berada di wilayah Jakarta Timur grumosol tergolong dalam ordo vertisol. Vertisol merupakan tanah dengan kandungan lempung yang sangat tinggi. Vertisol sangat lekat ketika basah, dan menjadi pecah-pecah ketika kering. Vertisol memiliki keampuan menyerap air yang tinggi dan juga mampu menimpan hara yang dibutuhkan tanaman. Grumosol sendiri merupakan tanah dengan warna kelabu hingga hitam serta memiliki $\mathrm{pH}$ netral hingga alkalis. Di Indonesia, jenis tanah ini terbentuk pada tempat-tempat yang tingginya tidak lebih dari $300 \mathrm{~m}$ di atas permukaan laut dengan topografi agak bergelombang hingga berbukit, temperatur rata-rata $25 \mathrm{oC}$, curah hujan $<2.500 \mathrm{~mm}$, dengan pergantian musim hujan dan kemarau yang nyata. Batasbatas wilayah Jakarta Timur, antara lain :
1. Sebelah utara berbatasan dengan kota administrasi Jakarta Utara dan Jakarta Pusat.

2. Sebelah timur berbatasan dengan Kota Bekasi.

3. Sebelah selatan berbatasan dengan Kota Depok.

4. Sebelah barat berbatasan dengan kota administrasi Jakarta Selatan

Wilayah Meester Cornelis (kemudian akan disebut dengan nama Jakarta Timur saja) pada tahun pada tahun 1815 penduduk Jakarta Timur berjumlah 7.217 jiwa, bermukim di kota lama dan daerah sekitarnya, seluas 2 mil persegi. Mungkin yang dimaksudkan adalah kota depan (voorstad) timur. Jadi belum termasuk di dalamnya daerah Weltevreden yang sejak zaman Daendels sudah berfungs sebagai pusat pemerintahan. Pada tahun yang sama Raffles juga melaporkan jumlah penduduk kabupaten. jumlah tersebut termasuk di dalamnya 7.217 jiwa yang dilaporkan sebagai penduduk kota Jakarta Timur dan sekitarnya. Jadi tampak bahwa secara umum jumlah penduduk Jakarta Timur mengalami kenaikan.

Kenaikan yang mencolok antara lain terjadi pada tahun 1848-1850 berjumlah 64.798 jiwa atau sekitar $28 \%$. Kemudian antara tahun 1865-1868 berjumlah 405.149 jiwa atau sekitar $44 \%$ selama 3 tahun. Kenaikan jumlah penduduk secara umum disebabkan menurunnya angka kematian orang Eropa mencapai 227.7 perseribu orang, turun menjadi 54,1 perseribu orang pada tahun 1844. Hal itu erat kaitannya dengan semakin meningkatnya kesehatan penduduk terutama setelah ditemukannya kina sebagai obat anti malaria, yang pada waktu-waktu sebelumnya banyak mendatangkan kematian. Selain itu air minnum yang sebelumnya diambil dari Kali Ciliwung, sejak tahun 1843 diambil dari sumur bor, terutama di daerah-daerah orang-orang Eropa bermukim. Dalam 
perkembangannya kemudian, air yang diperoleh dari sumur bor itu ditampung dalam reservoir (bak penampung), lalu dialirkan dengan pipa ledeng ke seluruh kota.

Pada awal tahun 1950-an, jumlah penduduk yang bertempat tinggal di Jakarta, yang pada masa itu masih berbentuk Kota Praja Jakarta Raya, relatif belum terlalu padat. Jumlahnya sekitar 1,4 juta orang. Jumlah penduduk yang belum terlalu padat ini tercermin dari lokasi pusat pertokoan serta sentra bisnis yang hanya terletak di wilayah tertentu saja, belum mencakup seluruh wilayah Jakarta. Pertambahan jumlah penduduk mulai terlihat di pertengahan tahun 1950an dan terus bertambah hingga saat ini. Perubahan jumlah penduduk dari tahun 1950-an hingga 1960-an mencapai 100\%. Jumlah penduduk yang semula 1,4 juta jiwa pada tahun 1950-an, kemudian bertambah menjadi 3 juta jiwa pada awal tahun 1960-an. Pertambahan jumlah penduduk di Jakarta ini salah satunya dikarenakan adanya urbanisasi dari luar Jakarta, mereka ini merupakan penduduk yang sebelumnya mengungsi ke daerahdaerah ketika perang kemerdekaan.

Setelah Orde Lama berakhir, pemerintahan rezim Orde Baru mengambil alih pemerintahan pusat maupun daerah. Khususnya wilayah Jakarta, pada masa pemerintahan Orde Baru dipimpin oleh Gubernur Ali Sadikin (diangkat sejak tahun1966 oleh Presiden Soekarno). Pada masa Ali Sadikin di tahun 1976 penduduk di kota Jakarta berjumlah 5. 745 . 675 jiwa, antara rentang periode 1961-1971 menurut Ali Sadikin penduduk berkembang dengan rata-rata 5,8\% setahun dimana $2,5 \%$ dari pertambahan alamiah dan 3,3\% bersumber dari urbanisasi (Sadikin, 1977:23). Saat ini ditahun 2011 menurut sensus penduduk yang dilakukan oleh Badan Pusat Statistik jumlah penduduk DKI Jakarta berjumlah sebesar 2.693.896 jiwa dengan luas wilayah 188,19 km2 (www.jakarta.go.id). Hasil pertanian dan perkebunan, wilayah Jakarta Timur merupakan hasil komoditi utama. Keragaman komoditi yang dimiliki di Jakarta Timur itu mendorong bangsabangsa asing untuk turut memanfaatkannya. Karena itu, Belanda sering mengirim berbagai komoditas ke luar negeri. Keunggulan lokasi di Jakarta Timur menjadi salah satu pendorong terjadinya interaksi dan komunikasi dengan berbagai bangsa lain di dunia. Berbagai komoditi di Jakarta Timur sangat dibutuhkan bangsa-bangsa di dunia. Selain itu, Jakarta Timur juga merupakan salah satu daerah pemasaran berbagai komoditas bangsa-bangsa lain. Mata pencaharian masyarakat Jakarta Timur saat ini bisa dibedakan menjadi dua jenis mata pencaharian :

1. Mereka yang berada di tengah kota menunjukkan mata pencaharian yang bervariasi, misalnya sebagai pedagang, pegawai pemerintah, pegawai swasta, buruh, tukang seperti membuat meubel.

2. Mereka yang berada di daerah pinggiran hidup sebagai petani sawah, buah-buahan, pedagang kecil, memelihara ikan, dan sekarang di antara mereka banyak yang menjadi buruh pabrik dan lain-lain.

Tinjauan Umum Sejarah Villa Nova Hingga Pasca Kemerdekaan

Sejak dimulainya era liberalisasi ekonomi pertama di Hindia-Belanda melalui pengesahan Undang-Undang Agrarischwet, Hindia-Belanda memasuki masa awal pembentukan masyarakat kapitalisme. Masuknya modal asing dari luar Hindia-Belanda, dapat dilihat dalam bentuk berdirinya perusahaan-perusahaan dan industri perkebunan dan manufaktur dihampir seluruh tanah Jawa. Khususnya di wilayah Jakarta areal-areal industri perkebunan tumbuh berdampingan 
dengan kantor-kantor pemerintahan dan dagang, gudang, toko-toko kelontong, sarana transportasi untuk orang dan barang, serta rumah-rumah penduduk yang berada dalam skema kota perdagangan dan perniagaan.

Persebaran dari infrastruktur ekonomi di Jakarta, secara umum dapat digambarkan sebagai berikut : di wilayah utara Jakarta berdiri cukup banyak gudang-gudang penyimpanan barang baik yang akan diekspor maupun barangbarang impor yang akan masuk ke wilayah Jakarta dan pedalaman. Sementara itu kampung-kampung tempat berdiam para buruh-buruh angkut pelabuhan berada di sekitar pinggir gudang dengan keadaan yang kumuh dan padat. Rumah-rumah penduduk Tionghoa berada di sepanjang jalan raya yang menghubungkan pelabuhan dengan pusat kota dan pemerintahan, selain itu kantorkantor dagang milik pemerintah dan swasta tertata di sekitar pusat pemerintahan Belanda.

Sementara itu pemukiman penduduk dan tempat-tempat perkebunan serta pertenakan miliki pengusaha Eropa berada di wilayah pinggiran Jakarta. Sebagian wilayah tersebut berada di sekitar pinggiran Jakarta bagian Timur, seperti Meester Cornelis, Pasar Rebo, Cililitan, Kampung Rambutan, Condet, hingga perbatasan antara Tanjung timur dengan Tanjung Barat. Wilayah-wilayah yang disebutkan itu adalah milik orang Eropa, yang ditandai degan sebuah bangunan besar pada masanya dan di dalamnya juga terdapat pemukiman penduduk pribumi. Bangunan besar tersebut dikenal dengan nama Villa Nova, sebuah bangunan yang berarsitektur Eropa Gotick tersebut tidak satupun sumber yang menyatakan waktu pembangunannya. Akan tetapi melalui beberapa sumber pula menyatakan bahwa bangunan tersebut dibangun oleh William Vincent Helvetius van Riemsdijk, yang tidak lain adalah anak dari Gubernur Jendral Jeremias van Riemsdijk pada masa VOC di tahun 1775-1777. Setelah wafatnya William Vincent Helvetius van Riemsdijk bangunan Villa Nova beserta tanah yang mengelilinginya dari Cililitan, Condet, hingga Kampung Rambutan dan Cijantung dikelola oleh anaknya Daniel Cornelis Helvetius van Riemsdijk.

Daniel Cornelis Helvetius van Riemsdijk adalah seorang pengusaha besar yang cukup sukses dalam bidang peternakan sapi. Produk utama dari maatschappij (perusahaan) yang dimiliki oleh Daniel Cornelis Helvetius van Riemsdijk adalah susu, hal ini dapat dilakukan karena pada masa jayanya Daniel Cornelis Helvetius van Riemsdijk memiliki 6000 ekor sapi yang berada di sepanjang tanah partikelir miliknya (Mukhti, 2012:30). Selain itu Daniel Cornelis Helvetius van Riemsdijk juga memiliki para penduduk pribumi yang bermukim diatas tanah partikelir yang dimilikinya tersebut sebagai pekerja dalam usaha peternakan yang didirikannya.

Perjalanan dan perkembangan ekonomi di Hindia-Belanda selanjutnya menghadapi tantangan yang cukup sulit dan mengalami penurunan pada saat meletusnya Perang Dunia I di tahun 1914. Pada masa itu cukup banyak perusahaan di Hindia-Belanda yang gulung tikar, dan aset-aset produksi seperti tanah partikelir banyak yang terbengkalai karena kekurangan modal untuk dikelola dan ditinggalkan oleh para penduduk pribumi karena jumlah pajak yang cukup memberatkan (Sahab, Republika 7 April 2006).

Keadaan ekonomi yang tidak menentu karena dampak perang dunia I di bumi Eropa membuat banyak pengusaha di Hindia-Belanda tidak meneruskan usahanya karena gulung tikar. Keberadaan mereka sebagai pengusaha di tanah-tanah partikelir di Hindia-Belanda 
digantikan oleh pengusaha dari Asia yang menginvestasikan dananya untuk membangun usaha industri perkebunan di Jawa. Pada awal tahun 1900-an, tanah partikelir di Tanjung Timur yang diatasnya berdiri bangunan Villa Nova, disewa oleh seorang pengusaha yang berasal dari China, bernama Tjaling Ament. Keberadaan Tjaling Ament sebagai penyewa tanah partikelir di Tanjung Timur tidak berlangsung lama karena kemudian ia meninggal dunia pada tahun 1903 di usia 76 tahun (Surat Kabar Bintang Betawi, 18 November 1903).

Setiap terjadi pergantian pemilik dari tanah partikelir di Tanjung Timur keadaan ekonomi para masyarakat pribumi yang bekerja di tanah partikelir tersebut tidak berubah. Mereka mengalami banyak penindasan yang dilakukan oleh tuan tanah. Penarikan pajak yang cukup tinggi serta perlakuan yang semena-mena oleh tuan tanah membuat para petani pribumi yang bekerja di tanah partikelir melakukan perlawanan dalam bentuk protes kepada Landraad (pengadilan). Kasus protes dan perlawanan yang cukup besar sempat di dokumentasikan oleh pemerintah kolonial Belanda ialah perlawanan yang dilakukan oleh Entong Gendut dan pengikutnya terhadap pemilik Villa Nova dan tanah partikelir di Tanjung Timur yang bernama Nyonya Van der Vasse Rollinson (Laporan Gerakan Protes di Jawa, 1981: XL; Mukthi, 2012: 29).

Perlawanan yang dilakukan oleh Entong Gendut terhadap pemilik tanah partikelir di Tanjung timur tersebut, disebabkan oleh rasa empati dari Entong Gendut terhadap petani setempat yang bernama Taba. Perlawanan tersebut berakhir dengan meninggalnya Entong Gendut ditembus timah panas polisi kolonial Belanda, dan beberapa pengikut Entong Gendut melarikan diri dari Tanjung Timur.
Melalui serangkaian penjelasan mengenai pembangunan dan perkembangannya Villa Nova merupakan sebuah bangunan yang tidak hanya berbentuk secara fisik semata, akan tetapi juga memiliki nilai-nilai dan simbol yang melekat di dalamnya. Secara umum dapat dikatakan bahwa Villa Nova memiliki nilai ekonomis sebagai pusat ekonomi yang berada di wilayah pingiran kota Jakarta, dalam bentuk tempat peternakan. Sebagai simbol sosial, bangunan Villa Nova merupakan simbol status sosial dari masyarakat Eropa untuk membedakan dengan para penduduk pribumi. Sementara itu, keberadaan Villa Nova secara politis memberikan gambaran secara politis terhadap kekuasaan kolonial di daerah pinggiran Jakarta.

\section{Bangunan Villa Nova pada Masa Orde Baru (Infrastruktur Pemerintahan dan Keterpinggiran)}

Infrastruktur Pemerintahan (Asrama Polisi)

Setelah bangsa Indonesia merdeka dan mengalami proses panjang untuk menghadapi perlawanan Belanda dalam bentuk Agresi Militer I di kota Jakarta, keberadaan Villa Nova masih tetap menjadi bangunan megah di wilayah Tanjung Timur. Setelah perundingan Konfrensi Meja Bundar yang menandai angkat kakinya pemerintahan kolonial Belanda di Indonesia, tantangan terberat lainnya adalah memulihkan ketertiban dan keamanan yang ada di tanah-tanah partikelir pinggiran Jakarta. Menurut beberapa sumber menjelaskan bahwa tanah-tanah partikelir mengalami banyak konflik dalam bentuk pergolakan dan gangguan kriminalitas berupa pencurian dan perampokan (Cribb, 1990: 20, 96; Asep Suryana dalam Taufik Abdullah dan Sukri Abdurrachman, 2011: 91).

Situasi keamanan yang tidak kondusif memaksa pihak pemerintah 
Republik Indonesia, melalui Kepolisian Republik Indonesia beserta kekuatan Tentara Nasional Indonesia melakukan tugas-tugas pengamanan di wilayah pinggiran Jakarta Selatan tersebu, dengan menggunakan Bangunan Villa Nova sebagai markas satuan keamanan di pinggiran Jakarta Selatan tersebut. Fenomena pengambil alihan bangunanbangunan bekas pemerintah Belanda dan gedung-gedung kantor, pada masa kemerdekaan dan pasca kemerdekaan menjadi fenomena umum. Hal ini dilakukan untuk melakukan konsolidasi bagi pembentukan tata kelola pemerintahan Republik Indonesia dari pusat hingga ke level daerah.

Bangunan Villa Nova memiliki fungsi yang cukup penting dalam upaya untuk memulihkan keamanan dan ketertiban di wilayah bagian timur dan selatan Jakarta. Seperti dalam menghadapi perlawanan Laskar Bambu Runcing yang selalu melakukan kegiatan kriminal di wilayah Ciganjur JakartaSelatan (Suryana, 2011: 94). Satuan keamanan yang melibatkan Kepolisian Republik Indonesia dan Tentara Nasional Indonesia merancang strategi penumpasan di Gedung Villa Nova, serta menggunakan ruang bawah tanah bangunan Villa Nova sebagai penjara bagi para pelaku kriminil yang tertangkap.

Gangguan keamanan yang terjadi di sepanjang wilayah pinggiran selatan Jakarta, cukup besar dan kuat karena cukup banyak melibatkan para laskarlaskar yang pernah terbentuk pada masa perang kemerdekaan. Seperti yang dijabarkan oleh Asep Suryana (2011: 94) bahwa cukup banyak laskar-laskar rakyat pasca revolusi yang terbentuk, kemudian melakukan perlawanan terhadap pemerintah pusat sebagai bentuk ketidakpuasan kebijakan re-organisasi kekuatan militer Republik Indonesia. Keadaan ini tidak hanya mampu ditanggulangi oleh kekuatan Kepolisian Republik Indonesia semata, maka untuk menanggulangi keadaan demikian Tentara Nasional Indonesia dilibatkan untuk melakukan penumpasan.

Tentara Nasional Indonesia melakukan kerja invasi terhadap kekuatan pemberontak, yakni dengan menguasai setahap demi setahap wilayah di pinggiran Jakarta Selatan. Salah satunya ialah dengan menempatkan landbouw untuk dijadikan markas militer Yon Zipur (Surat Kabar Merdeka, 11 Maret 1953), maka dengan demikian Bangunan Villa Nova dikembalikan kepada Kepolisian Republik Indonesia sebagai markas Polisi di perbatasan antara Jakarta bagian Timur dan Selatan. Dengan kembalinya bangunan Villa Nova sebagai markas Kepolisian Republik Indonesia di pinggiran Jakarta Timur dan upaya pemulihan keamanan yang berjalan dengan baik oleh Tentara Nasional Indonesia, maka tugas-tugas dan fungsi keamanan kembali dapat dijalankan di daerah Tanjung Timur.

Seiring dengan perkembangan waktu memasuki medio tahun 1960-an, situasi ekonomi Indonesia semakin sulit akibat konflik politik dalam level nasional membuat Jakarta memasuki babak baru gangguan keamanan. Peristiwa nasional di tahun 1965 dalam bentuk penculikan para Jenderal dan perwira Tentara Nasional Indonesia Angkatan Darat membuat situasi keamanan di Jakarta semakin mencekam. Dalam situasi penumpasan peristiwa G30/S Bangunan Villa Nova menjadi tempat untuk memenjarakan para loyalis dan orang-orang yang dianggap menjadi simpatisan Partai Komunis Indonesia di wilayah Jakarta Timur.

Bangunan Villa Nova menerima para tahanan loyalis Partai Komunis Indonesia yang ditangkap dari daerah Pondok Gede Jakarta Timur. Jumlah tahanan yang cukup banyak membuat 
kapasitas ruang bawah tanah di Bangunan Villa Nova tidak mampu menampung jumlah para tahanan, maka dari itu posisi ruang penjara bawah tanah bangunan Villa Nova hanya menjadi shelter sementara bagi para tahanan sebelum dibuang ke daerah Pulau Buru. Tingkat kriminalitas dan gangguan ketertiban dan keamanan yang meningkat karena peristiwa G-30/S tersebut membuat pihak Kepolisian Republik Indonesia menigkatkan jumlah anggotanya. Meskipun tidak didapatkan data valid mengenai penambahan jumlah anggota polisi yang ada dan ditugaskan di wilayah Tanjung Timur, hal tersebut dapat dibuktikan melalui pembangunan gedung asrama yang diperuntukan bagi anggota-anggota polisi yang bertugas di Tanjung Timur.

$$
\text { Bangunan-bangunan asrama }
$$

untuk polisi yang bertugas di Tanjung Timur itu dibangun di sebelah timur dan selatan bangunan Villa Nova. Menurut sumber peningkatan jumlah anggota polisi setiap tahun selalu mengalami peningkatan hampir 2,3\%, dan hal ini yang membuat jumlah anggota polisi yang tinggal di daerah Tanjung Timur semakin meningkat jumlahnya. Perluasan bangunan bagi asrama angota polisi di Tanjung Timur tidak hanya berhenti dalam bentuk gedung saja, akan tetapi mulai berbentuk rumah-rumah tinggal.

Setelah berakhirnya pemerintahan

Orde Lama dan diganti dengan pemerintahan Orde Baru, terjadi perubahan besar-besaran dalam orientasi kebijakan keamanan dan ketertiban di Indonesia. Kebijakan ekonomi Developmentalism (pembangunan) yang dicanangkan oleh pemerintahan Orde Baru membuat fungsi pengamanan dan keamanan semakin menempati posisi yang strategis. Guna menghindari kegaduhan dalam level sosial dan politik, pemerintahan Orde Baru mengunakan aparatur militer dan keamanan sipil untuk terjun langusung ke akar rumput memobilisasi dan meng- awasi kehidupan sosial masyarakat sesuai dengan kepentingan dan tujuan pemerintahan Orde Baru.

Dengan peningkatan posisi aparatur keamanan dan militer di Indonesia, maka tugas-tugas dan kerja Kepolisian Republik Indonesia semakin besar, hal ini mendorong tingkat intensitas kerja yang cukup tinggi dan membutuhkan infrastruktur penunjang yang cukup besar pula. Perubahan dan pergantian penunjang kerja Kepolisian Republik Indonesia, dapat terwujud setelah terjadinya peristiwa kebakaran asrama polisi yang melanda asrama polisi dan kantor polisi di Tanjung Timur. Pada tahun 1970, bangunan Villa Nova yang tidak lain adalah kantor polisi untuk wilayah Jakarta Timur mengalami peristiwa kebakaran yang juga melanda asrama/ tempat tinggal polisi (Mukhti, 2011: 30).

\section{Peristiwa Kebakaran Tahun 1970 dan Kebijakan Tidak di Fungsikan Kembali}

Sejatinya sebelum terjadinya pertistiwa kebakaran yang melanda Gedung Villa Nova, kantor polisi sudah dipindahkan ke tempat lain di wilayah Jakarta Timur lainnya. Jadi sebelum terjadinya peristiwa tersebut aktivitas kepolisian yang berada di Bangunan Villa Nova sudah dipindahkan, hal ini yang membuat keadaan Gedung Villa Nova kosong dan tidak ada penghuni. Keadaan kosong inilah yang kemudian dimanfaatkan oleh sebagian orang yang dianggap tidak bertanggung jawab, melakukan hal-hal yang tidak baik. Maka pada suatu ketika di tahun 1970 terjadi peristiwa kebakaran yang terjadi di lantai 3 (tiga) Villa Nova (Mukhti, 2012: 30).

Peristiwa kebakaran tersebut tidak hanya terjadi pada bangunan Villa Nova, akan tetapi juga terjadi pada sebagian asrama polisi yang digunakan sebagai tempat tinggal para polisi. 
Setelah terjadinya peristiwa kebakaran yang melanda bangunan Villa Nova, tidak ada yang dilakukan oleh pemerintah Daerah Khusus Ibu Kota Jakarta, sebagai pemilik dari lahan tersebut. Langkah yang dilakukan oleh Pemerintah Daerah Khusus Ibu Kota Jakarta, hanya mengeluarkan surat keputusan berupa penetapan pemerintah daerah Jakarta kepada bangunan sisa dari Villa Nova sebagai bangunan Cagar Budaya (Pemda DKI Jakarta, 1976:211).

Seiring waktu yang berjalan hingga masuk dasawarsa milenium saat ini keberadaan bangunan Villa Nova yang berangsur-angsur mulai rapuh dan runtuh belum mendapatkan perhatian dari pemerintah daerah Jakarta maupun dari para pegiat kajian kesejarahan. Hingga saat ini belum ada kajian sejarah yang secara khusus mengkaji secara mendalam mengenai kajian sejarah bangunan Villa Nova.

Menetapkan sisa-sisa bangunan Villa Nova ke dalam benda-benda yang diangap sebagai benda yang dilindungi, tanpa melakukan renovasi maupun pemugaran dan perawatan sejatinya bukanlah langkah yang dapat dinilai masih kurang. Dinas atau divisi yang bertanggung jawab terhadap keberadaan Bangunan Villa Nova di Jakarta menurut garis komando pemerintahan DKI Jakarta berada dalam pengawasan dinas yang berada dalam tata pemerintahan Daerah Khusus Ibu Kota Jakarta.

Kesadaran tentang pentingnya keberadaan sisa bangunan Villa Nova dewasa ini untuk kepentingan Bendidikan, kebudayaan dan pariwisata mulai dilanjutkan kembali pada tahun 2016, saat dikeluarkannya keputusan Gubernur tahun 2016 tentang percepatan dan penataan pengembangan lahan buah Condet dan Villa Nova sebagai destinasi wisata.

\section{Re-Posisi dan Rekonstruksi Keberadaan Gedung Villa Nova}

Dalam mencoba melukiskan sejarah, sering kali kita berhadapan dengan sumber-sumber yang berbentuk artefak (non-dukumen). Sama seperti jenis-jenis sumber lainnya seperti lisan dan tulisan, kita semua pasti akan melakukan interpretasi dan penafsiran terhadap sumber artefak tersebut, akan tetapi yang membedakan ialah minimnya data, keterangan serta informasi yang akan kita dapatkan melalui sumber artefak tersebut, terlebih jika yang kita hadapi hanya berupa tugu, monumen dan patung (di luar dari prasasti).

Upaya untuk menggali dan memahami masa lampau tidak dapat dipisahkan dari ketersediaan sumber yang menjadi satu faktor penentu dapat atau tidaknya, masa lalu tersebut di rekonstruksi. Bangunan, monumen, tugu, prasasti merupakan sumber sejarah yang dapat digunakan dalam memahami masa lampau dengan melihat segi-segi yang berhubungan dengan keberadaannya. Pada saat ini bagaimana reruntuhan bangunan Villa Nova seolah-olah menjadi terbengkalai kita dapat mencoba memahaminya melalui uraian tentang peran dari pemerintah daerah sebagai penanggung jawab dari keberadaan bangunan Villa Nova tersebut. Selain mencoba melihat seberapa besar peranan pemerinatah terhadap bangunan Villa Nova, kita juga harus memahami secara lebih mendalam bagaimana respon masyarakat dan peran masyarakat terhadap keberadaan bangunan Villa Nova.

\section{Peran Pemerintah}

Masa-masa pemerintahan Orde Baru merupakan sebuah masa dari sejarah Indonesia, yang banyak menjelaskan bagaimana bangsa ini membangun pola-pola kehidupan ekonominya (Anne Both..). Upaya untuk membangun 
sektor ekonomi dan mensejahterakan kehidupan masyarakat Indonesia menjadi program utama pemerintah Orde Baru melalui program pembangunan berjangka (Repelita). Orientasi pemerintahan pusat tersebut memberikan konsekuensi berupa keseragaman berfikir dan pengawasan kehidupan sosial-politik yang cukup ketat. Maka dari itu kehidupan sosial hingga wacana-wacana kesejarahan masuk dalam kontrol pemerintah.

Dalam penulisan sejarah Indonesia yang berkaitan dengan sejarah lokal Jakarta, keberadaan atau tulisan mengenai Bangunan Villa Nova beserta sejarah dari Tanjung Timur hanya sedikit sekali dimuat di dalamnya, bahkan bisa dikatakan hanya selintas lalu. Tanjung Timur beserta Bangunan Villa Nova yang memiliki peran peting dalam kehidupan ekonomi masyarakat Jakarta di pinggiran timur Jakarta, menjadi hilang dalam narasi mengenai dinamika kehidupan politik, peran orang-orang besar dan peristiwa-peristiwa kemiliteran. Sepertinya hingga saat ini belum ada satupun karya ilmiah yang disusun oleh para sarjana sejarah dan arstitektural yang mengkaji secara fokus dan khusus tentang keberadaan bangunan Villa Nova dan Tanjung Timur.

Meskipun pemerintah pada masa Orde Baru di tahun 1972 dan pemerinatah era reformasi ditahun 2016 sudah Manempatkan bangunan Villa Nova sebagai wilayah cagar budaya, bersejarah dan menjadi salah satu destinasi wisata di kota Jakarta Timur, akan tetapi kita masih bisa melihat bagaimana keadaan sisa-sisa reruntuhan bangunan Villa Nova yang tidak tersentuh oleh kebijakan pemerintah.

Situasi ekonomi yang selalu mengalami pasang surut sejak peristiwa krisis ekonomi di tahun 1998, seperti membuat masyarakat di Jakarta melupakan mengenai keberadaan bangunan ini (sebelumnya sudah ditekankan bahwa
Tanjung Timur merupakan daerah penghasil keuntungan bagi kolonial melalui komoditi susu). Keadaan dalam bidang politik yang tergambar melalui hirukpikuk perebutan posisi-posisi strategis dalam bingkai kekuasaan sepertinya sudah melupakan keberadaan bangunan Villa Nova yang sejatinya sejak akhir abad ke-17 sudah memiliki legitimasi nilai-nilai politis yang melekat di dalamnya. Dalam bidang pendidikan, berita atau informasi yang menceritakan mengenai keberadaan bangunan Villa Nova beserta dinamika wilayah Tanjung Timur juga tidak mampu untuk menembus masuk dalam substansi mata pelajaran sejarah di sekolah-sekolah. Bahkan dalam level pendidikan dengan muatan lokal, keberadaan bangunan Villa Nova tidak diikutsertakan dalam rangkain materi pembelajaran yang akan diberikan kepada siswa-siswa sekolah dasar hingga menengah atas di kota Jakarta.

Keadaan ini mungkin terjadi bukan tanpa sebab, kesadaran terhadap masa lampau yang dikatakan sebagai hal yang cukup penting oleh Alvin Tofler merupakan kendala yang selalu dihadapi oleh setiap suku bangsa dan masyarakat di dunia dewasa ini (Widja, 2002: 27). Menghadapi perubahan-perubahan yang berjalan dengan sangat cepat dan cenderung tidak stabil, faktor mengenai kemampuan memahami masa lampau dan memperkirakan arah perkembangan masa depan menjadi satu faktor yang cukup fundamental. Melalui upaya pemerintah menempatkan bangunan Villa Nova sebagai salah satu cagar budaya, bangunan bersejarah dan destinasi wisata, sejatinya dapat dikatakan sebagai langkah awal untuk mengembalikan kembali mengenai konsep kesadaran sejarah bagi masyarakat dan khususnya generasi yang akan datang. Bangunan Villa Nova dapat menjadi upaya bagi kita untuk memamahi bagaimana bangsa ini terbentuk, melalui jalan kolonialisasi yang cukup panjang, 
melewati pengorbanan yang tidak terhingga dalam meraih kemerdekaan, menghadapi perseteruan dengan sesama saudara dan lainnya, yang sekiranya semua disaksikan oleh bangunan yang bernama Villa Nova.

Hiruk-pikuk situasi nasional maupun lokal kota Jakarta, yang seolaholah melupakan keberadaan bangunan Villa Nova merupakan satu ironi tersendiri. Seperti data yang didapatkan dalam penelitian ini, seorang guru yang mengajar mata pelajaran Seni Budaya dan Keterampilan (SBK) di salah satu sekolah swasta di daerah Condet, mengaku tidak mengetahui sejarah bangunan Villa Nova, maupun gambaran keberadaannya yang utuh (wawancara dengan bapak Santoso, 11 Mei 2016). Bahkan generasi muda yang lahir di sekitar wilayah Pasar Rebo-Jakarta Timur tidak mengetahui jika bangunan runtuh yang berada di samping komplek asrama polisi tersebut memiliki peran penting bagi perkembangan daerah Pasar Rebo (wawancara dengan saudara Aji Dimas, 19 Mei 2016). Pasca peristiwa reformasi di tahun 1998, melalui kesadaran dan tekanan berbagai pihak yang menyatakan bahwa merasa perlu untuk kembali menanamkan kesadaran masa lampau, maka kita merasa perlu menyambut baik hadirnya keputusan Gubernur DKI Jakarta ditahun 2016 ini, mengenai aturan dan program percepatan pembangunan di wilayah-wilayah atau tempat-tempat yang dianggap memiliki nilai budaya, sejarah dan pariwisata.

\section{Konsep Desain Infografik Gedung Villa Nova Sebagai Media Pendidikan Sejarah}

Tinjauan Karya Desain Infografis sebagai insprasi dan standar informasi.

Tinjauan karya di sini mempunyai kemiripan fungsi dengan tinjauan pustaka. Jika pada tinjauan pustaka menempatkan aspek penelitian terdahulu, maka tinjauan karya lebih menekankan kepada karya desain infografis yang pernah dirancang oleh desainer maupun praktisi yang kemudian dijadikan inspirasi dan standar yang nantinya akan ditetapkan sebagai dasar perancangan. Berikut adalah tinjauan karya yang dapat dijadikan contoh dalam pembuatan desain infografis Gedung Villa Nova, di antaranya.

1. Wood Naturally - Wood Wise (Infographics Animation Production)

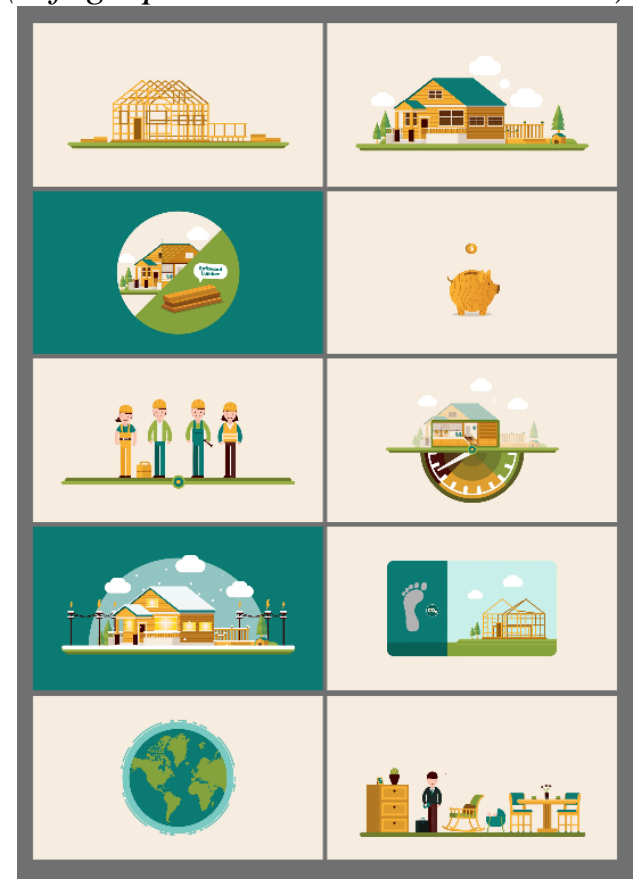

Gambar 1. Contoh Tayangan Infografis Wood Naturally

2. History of The Internet.

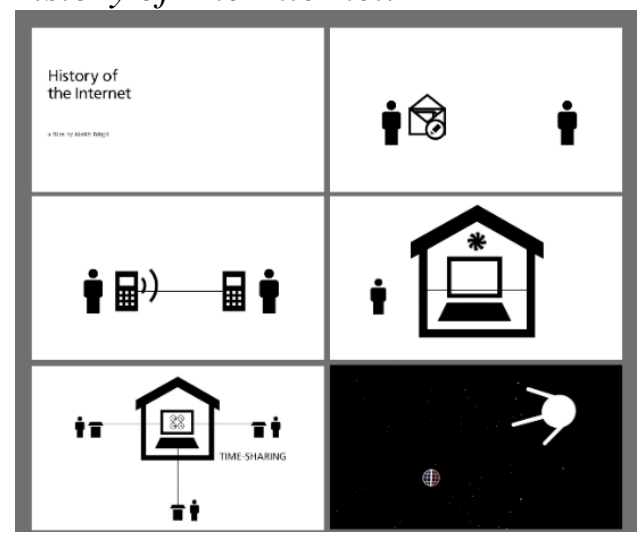




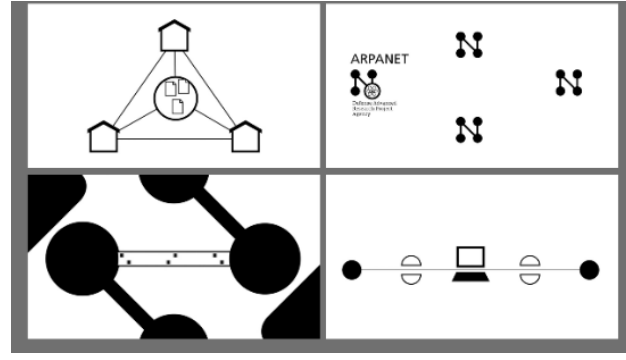

Gambar 2. Contoh Tayangan Infografis History of The Internet

\section{Bentuk Konsep Desain Infografis}

Berikut adalah aspek-aspek yang akan direncanakan dalam menyusun konsep desain infografis Gedung Villa Nova sebagai media pendidikan sejarah. (1) peneliti akan menggunakan dubber atau istilah lainnya yaitu voice over sebagai orang yang akan menjabarkan alur informasi yang terdapat dalam film,
(2) peneliti akan menggunakan font sans serif untuk mengkhususkan kelompok atau target materi sejarah ini pada kalangan dewasa yang menyukai informasi tentang sejarah khususnya di daerah DKI Jakarta. (3) peneliti akan mentrasformasikan bentuk Gedung Villa Nova menjadi ikon. (4) warna-warna yang dipilih oleh peneliti adalah warna hitam, merah, kuning-oranye, dan hijau sebagai keterwakilan dari pembahasan ini yaitu sejarah (merah), kuning-oranye (pengetahuan), hijau (agraria-erat kaitannya dengan perkebunan di daerah Condet) dan hitam (yang memberikan kesan kesederhanan). Berikut ini adalah contoh draft penerapan yang telah peneliti lakukan.

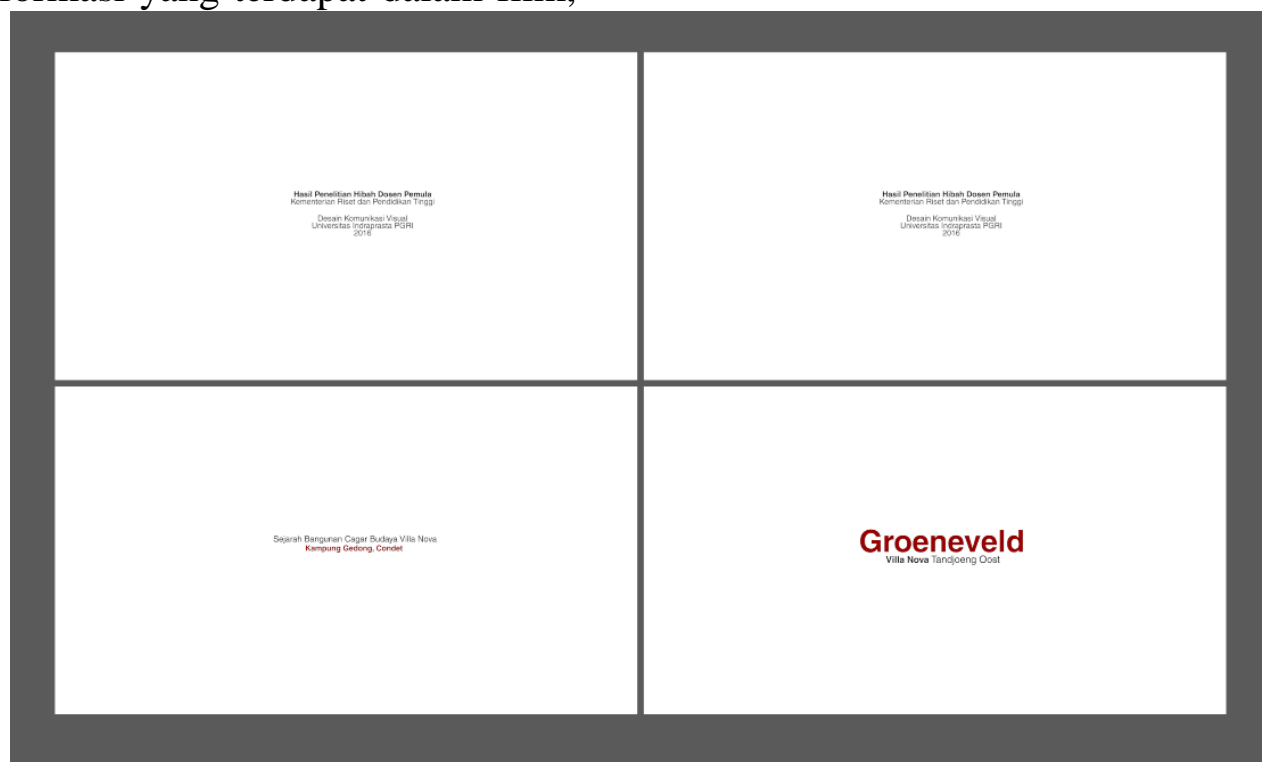

Gambar 3. Contoh Penerapan Konsep Introduction

\section{SIMPULAN}

Keberadaan bangunan Villa Nova saat ini sudah memprihatinkan dan jauh dari sebuah tempat sejarah, bentuk bangunan yang sudah rusak karena kebakaran dan area lahan yang sudah disorientasi fungsi dari yang seharusnya dikatakan sebagai cagar budaya adalah hal persoalan mendasar tetapi sangat vital apabila tidak diselesaikan. Melalui dua pendekatan desain dan sejarah, penelitian ini akan kembali merekonstruksi sejarah di balik keberadaan bangunan Villa Nova untuk menganalisis cerita, bentuk, fungsi dan kepentingan di zamannya. Keberadaan bangunan yang tidak mampu lagi dihadirkan dan diperbaiki kembali secara fisik, menjadi hal yang patut diangkat dan dihadirkan kembali dalam bentuk media informasi yang menarik dalam bentuk desain infografik rekonstruksi sejarah gedung Villa Nova Jakarta. Melalui kesadaran dan tekanan 
berbagai pihak yang menyatakan bahwa merasa perlu untuk kembali menanamkan kesadaran masa lampau, maka kita merasa perlu menyambut baik hadirnya keputusan Gubernur DKI Jakarta di tahun 2016 ini, mengenai aturan dan program percepatan pembangunan di wilayahwilayah atau tempat-tempat yang dianggap memiliki nilai budaya, sejarah dan pariwisata.

\section{DAFTAR PUSTAKA}

Buku :

Amri, A.A. (2013). Model Penelitian Desain Komunikasi Visual. PT. Cipta Caraka Nusantara: Jakarta.

Denzin, N. K. dan Yvonna S. L. (2009). Handbook Of Qualitative Research, Yogyakarta: Pustaka Pelajar.

Kartodirdjo, S. (1992). Pendekatan Ilmu Sosial dalam Metodologi Sejarah. Gramedia. Jakarta.

Ratna, N.K., (2010). Metodologi Penelitian: Kajian Budaya dan Ilmu-ilmu Sosial Humaniora Pada Umumnya. Pustaka Pelajar: Yogyakarta.

Safanayong, Y. (2006). Desain Komunikasi Visual Terpadu. Jakarta: Arte Intermedia

Shahab, A. (2002). Betawi: Queen Of The East. Jakarta: Republika

Walker, J.A. (2010). Desain, Sejarah, Budaya, Yogyakarta: Jalasutra

\section{Laporan Penelitian/Tesis :}

Amri, A., dkk. (2010). Narasi Simbolik Pada Artefak Gedung Djuang Sebagai Alat Konstruksi Sejarah Bekasi, Laporan Penelitian Program Studi Desain
Komunikasi Visual Universitas Indraprasta PGRI.

Kusliansjah, K. dan Adam R.. (2012).

Struktur Pesisir (Waterfront)

Kota Cirebon - Jawa Barat: Studi

Kasus Telaah Morfologi

Kawasan Pesisir Kelurahan

Panunan, Lemahwungkuk,

Kasepuhan, Kasunean - Kota

Cirebon. Laporan Penelitian

Arsitektur Kota, Lembaga

Penelitian dan Pengabdian

Kepada Masyarakat Universitas Katolik Parahyangan, Bandung.

Yanuarti, R. (2007). Perlindungan Hukum Terhadap Karya Arsitektur Cagar Budaya di Tinjau dari Undang-Undang Nomor 19 Tahun 2002 Tentang Hak Cipta: Studi Kasus Perlindungan Arsitektur Cagar Budaya di Kota Semarang. Tesis Magister Kenotariatan Program Pasca Sarjana Universitas Diponogoro, Semarang.

\section{Jurnal Ilmiah :}

Moechtar, M. S., dkk. (2012). Identifikasi Pola Pemukiman Tradisional Kampung Budaya Betawi Setu Babakan, Kelurahan Srengseng Sawah, Kecamatan Jagakarsa, Kota Administrasi Jakarta Selatan, Provinsi DKI Jakarta. EJurnal Agroekoteknologi Tropika, Vol. 1, No. 2, Oktober 2012: 135, ISSN: 2301-6515, http://download.portalgaruda.or g/ article.php? article $=16350$ \&val=99, diunduh 19 April 2015.

Wicandra, O.B. (2006). Peran Infografis Pada Media Massa Cetak. Jurnal Nirmana Vol. 8, N0. 1, Januari 2006: 44-50. 


\section{Artikel Internet :}

Maryadie, Zaky Al-Yamani, Trah Van Riemsdjik di Groeneveld: Lamalama Gedung itu dikenal dengan Sebutan Gedong, ditulis Senin 1 Februari 2010, diunduh 19 April 2015 ,

http://metro.news.viva.co.id/news lread/125991-

trah_van_riemsdjik_di_groeneve ld.
Rina Atriana, Napak Tilas Jakarta (18), Villa Nova, Saksi Bisu Pemberontakan Entong Gendut Kini Tinggal Puing, ditulis Jumat, 21 Juni 2013, diunduh 19 April 2015 ,

http://news.detik.com/read/2013/ 06/21/144349/ 2280319/10/1/ villa-nova-saksi-bisupemberontakan-entong-gendutkini-tinggal-puing. 